\title{
Electrical energy generation in a double- compartment microbial fuel cell using Shewanella spp. strains isolated from Odontesthes regia
}

\author{
Sandy L. Calderon ${ }^{1,2}$, Pilar García Avelino², Angélica María Baena-Moncada ${ }^{1,2}$, Ana Lucía Paredes-Doig and \\ Adolfo La Rosa-Toro ${ }^{1,2^{*}}$ i
}

\begin{abstract}
This study is focused on electrical energy generation in a double-compartment microbial fuel cell. Carbon felt impregnated with multi-walled carbon nanotubes was used as an anode, which contained gold nanoparticles and Shewanella spp. grown under aerobic conditions was used as a biocatalyst. The electrodes, used before and after biofilm growth, were characterized by scanning electron microscopy and cyclic voltammetry. The results revealed the formation of Shewanella spp. colonies on the electrode surface and electrochemical activity under aerobic and anaerobic conditions. During biofilm growth in Luria Bertani medium, a stabilized average power density of $281 \mathrm{~mW} \mathrm{~m}^{-2}$ was recorded. Subsequently, the cell reached a maximum current density of $0.11 \mathrm{~mA} \mathrm{~cm}{ }^{-2}$ after $72 \mathrm{~h}$ of operation and a coulombic efficiency of $65 \%$ under anaerobic conditions.
\end{abstract}

Keywords: Microbial fuel cell, Shewanella spp., Aerobic anodic chamber, Multi-walled carbon nanotubes, Gold nanoparticles

\section{Introduction}

In recent years, many researches have been focused on the study of microbial fuel cells (MFC) for conversion of chemical energy to electrical energy [1, 2]. MFCs generate energy through electron transfer from the microbial cell to the fuel cell anode. The ability of microorganisms to generate an electrochemical potential is naturally occurring in several microbial species such as the Gram-negative Shewanellaceae and Geobacteracea, which are called exoelectrogenic bacteria as they tend to produce electrochemically active biofilms on the electrodes (in particular the anodes) [2-4]. Researchers have reported electrochemical activity in the biofilm formation under anaerobic conditions $[5,6]$. The systems that use these

\footnotetext{
* Correspondence: toro@uni.edu.pe

${ }^{1}$ Research Laboratory of Applied Electrochemistry, National University of Engineering, Lima 01, Peru

${ }^{2}$ Center for the Development of Advanced Materials and Nanotechnology, National University of Engineering, Lima 01, Peru
}

bacteria require special conditions, such as the absence of oxygen. Therefore, their application is limited to use sludge inoculums and to apply MFC on seabed. For this reason, the study on energy generation for active bacteria in aerobic and anaerobic environments such as Shewanella spp., can widen the scope and application of these systems.

Shewanella spp., are Gram negative bacilli which have bacillary mobility with a single polar scourge, an important phenotypic feature is the production of hydrogen sulfide [7]. Shewanella spp. are distributed throughout the world, mainly in marine environments. On the one hand, they are capable of reducing substances such as nitrate, nitrite, thiosulfate and trimethylamine- $\mathrm{N}$-oxide [8]. The biofilm-forming ability has been described in detail for Shewanella oneidensis and Shewanella putrefaciens [9].

In order to obtain a high-power density of MFCs, electrodes with good electrical conductivity, large surface area and biocompatibility [1] are required. For this reason,

(c) The Author(s). 2020 Open Access This article is licensed under a Creative Commons Attribution 4.0 International License, which permits use, sharing, adaptation, distribution and reproduction in any medium or format, as long as you give appropriate credit to the original author(s) and the source, provide a link to the Creative Commons licence, and indicate if changes were made. The images or other third party material in this article are included in the article's Creative Commons licence, unless indicated otherwise in a credit line to the material. If material is not included in the article's Creative Commons licence and your intended use is not permitted by statutory regulation or exceeds the permitted use, you will need to obtain permission directly from the copyright holder. To view a copy of this licence, visit http://creativecommons.org/licenses/by/4.0/. 
carbonaceous electrodes have been widely used as well as the modification of their surfaces with metals: Ni/Co-based oxide/activated carbon [10], Pd/carbon cloth [11], and Fe/ CNT [12]. Despite their high performance, these electrodes have certain restrictions related to their low biocompatibility, laborious synthesis and high cost, which limit their use. In this regard, the use of commercial carbon felts (CF) turns out to be promising due to their large surface area and low cost [2]. Studies using this type of CF reported high power density values of 1 and $0.52 \mathrm{~W} \mathrm{~m}^{-2}$ [13-15]. However, these values are far less than the power densities values of some metal electrodes such as $\mathrm{Cu}$ and $\mathrm{Pt}$ with 40 and $78 \mathrm{~W} \mathrm{~m}^{-2}$, respectively. Thus, their surface modification has been proposed as a problem-solving strategy to improve the electric conductivity of electrodes. Gold nanoparticles (AuNPs) are considered a good alternative to facilitate electron transfer and increase the biocompatibility of the electrode due to their high conductivity [16]. In addition, the use of carbon nanotubes as good charge carriers with low resistivity of $10^{-5} \Omega \mathrm{cm}$ and good chemical stability [17] can increase surface area and electron transfer as have been reported in studies applied to MFC devices [18-20].

Therefore, this study evaluates the possibilities to generate electrical energy in a MFC that uses surface-modified CF with multi-walled carbon nanotubes (MWCNT) and AuNPs as anode and an isolate strain of Shewanella spp. as inoculum.

\section{Materials and methods Materials}

MWCNTs (> 95\% purity) used in the experiment were purchased from Chengdu Organic Chemicals Co.; glucose $(\geq 85 \%)$ was purchased from Microgen Culture Media-CDH; nutrient agar from Panreac AppliChem; blood agar base (dehydrated) from Thermo Scientific ${ }^{\text {тм }}$ Oxoid $^{\text {TM }}$ Columbia, all are analytical grade reagents for microbiological control. Oxidase test, catalase test, SIM (sulfide, indole, motility) agar, urea agar base, Simmons citrate agar, defibrinated sheep blood, and Gram staining set were used for microbial studies, polydiallyldimethylammonium chloride $(20 \mathrm{wt} \%)$, nafion $5 \%(\mathrm{w} / \mathrm{w})$ and L-tyrosine were purchased from Sigma Aldrich; potassium hexacyanide ferrate (II) (99\%), potassium hexacyanoferrate (II) trihydrate purum ( $\geq 99 \%$ ), potassium hexacyanide ferrate (III) (99\%), potassium hexacyanoferrate (III) (99\%), potassium chloride (>98\%), potassium chloride $(\geq 98 \%)$ and sulfuric acid (96\%) were purchased from Merck. All chemical reagents were used as received without further purification.

\section{Isolation, identification and maintenance of Shewanella spp. strain}

Thirty species of "pejerrey" Odontesthes regia that live in Ancon Bay (latitude; 11 46' 28.524" S and longitude $77^{\circ} 9^{\prime}$
43.992" W), Peru, were collected in February. These organisms were sliced and placed in $450 \mathrm{~mL}$ glass jar, with a third of the volume filled with the sliced pejerrey and then covered with seawater. All jars were incubated at $30{ }^{\circ} \mathrm{C}$ for their decomposition and bacterial growth for $24 \mathrm{~h}$.

For bacterial isolation, the samples were incubated for $24 \mathrm{~h}$ in seawater, then $1 \mathrm{~mL}$ of each of the jars was extracted, seeded in triplicate, cultured in test tubes with SIM medium, and incubated at $30^{\circ} \mathrm{C}$ for $24 \mathrm{~h}$ to obtain pure cultures. Those cultures with the bacterial colonies exhibiting the presence of hydrogen sulfide (black matter) were differentiated by streak plate technique, then transferred to individual plates with agar supplemented with fish soup ( $15 \mathrm{~g} \mathrm{~L}^{-1}$ of agar and $50 \mathrm{vol} \%$ of fish soup) at $30{ }^{\circ} \mathrm{C}$ for $24 \mathrm{~h}$.

Phenotypic identification, mobility, Gram staining and morphology were determined as described by Austin [21]. Biochemical tests were used for the identification of oxidase, catalase, indole production, hydrogen sulfide production, urea hydrolysis, gelatin hydrolysis, nitrate reduction, nitrite reduction, and hemolysis [22]. For the maintenance of the Shewanella strain, it was preserved in plates with nutrient agar and in agar slant tubes with nutrient agar.

Raman microscopy strain isolated from Shewanella spp. Shewanella spp. was incubated in $250 \mathrm{~mL}$ flasks, containing $25 \mathrm{~g}$ of Luria Bertani (LB) broth in $100 \mathrm{~mL}$ of ultrapure water. It was applied in a rotating bath $\left(37^{\circ} \mathrm{C}, 100 \mathrm{rpm}\right)$ for $24 \mathrm{~h}$. After incubation the grown bacterial cells were concentrated. For this, the bacterial solution was washed by centrifugation at $1000 \mathrm{rpm}$ in phosphate buffer at $\mathrm{pH} 7.2$ and stored under sterile conditions. The collected bacterial cells were suspended on a silk screen-printed gold electrode, dried for $24 \mathrm{~h}$ and then analyzed with a Raman spectroscopy. The rough gold surface with bacteria was mounted directly under the microscope lens and the bacterial colonies were excited using a $638 \mathrm{~nm}$ laser line. Surface Enhanced Raman spectroscopy analysis was performed through a Horiba Scientific XploRA spectrometer with a Charge Coupled Device detector. A 1200 lines $\mathrm{mm}^{-1}$ diffraction grating was used and measured in a range of 500$1200 \mathrm{~cm}^{-1}$, with a $50 \mathrm{X}$ objective and $50 \%$ laser power. The spectra were collected consecutively at $3 \mathrm{~min}$ per scanner. The positions of the spectral peaks were calibrated using silicon wafer of crystal as a reference.

\section{Bacterial population and growth conditions}

The Shewanella spp. strain was seeded on nutrient agar by streak-plating method and incubated at $30{ }^{\circ} \mathrm{C}$ for 24 h. They were transferred to a flask containing $100 \mathrm{~mL}$ of culture medium and, after $12 \mathrm{~h}, 3 \mathrm{~mL}$ of this solution were transferred to a flask containing $750 \mathrm{~mL}$ of $\mathrm{LB}$ broth. Finally, the bacteria were grown under aerobic conditions and constant agitation of $150 \mathrm{rpm}$ for $36 \mathrm{~h}$. 
Strain of $1 \times 10^{8} \mathrm{CFU} \mathrm{mL} \mathrm{m}^{-1}$ of Shewanella spp. was used as anodic biocatalyst in MFCs.

\section{Preparation of CF electrode modified with MWCNT-AuNPs (MWCNT-AuNPs/CF)}

Prior to carbon fiber surface modification, the synthesis of the AuNPs was performed using $100 \mathrm{~mL}$ of a $10^{-4} \mathrm{M}$ precursor solution of $\mathrm{HAuCl}_{4}$ at $\mathrm{pH} 9.5$ adjusted with $\mathrm{NaOH}$. The reduction was carried out with $3 \mathrm{~mL}$ of 0.01 $\mathrm{M} \mathrm{NaBH}_{4}$ at room temperature, obtaining ruby-red colloidal gold. Ten milliliters of $1 \mathrm{mM}$ tyrosine were used as stabilizing agents for nanoparticles [23]. Finally, the solution was heated to remove excess of unreacted borohydride ions, and the colloid was allowed to age for $24 \mathrm{~h}$. The nanoparticles were centrifuged three times at $12000 \mathrm{rpm}$ with a solution of $\mathrm{NaOH}$ at $\mathrm{pH} 9.5$.

The modification of MWCNT with recently synthesized AuNPs was performed using the layer-by-layer selfassembly technique [24] and three assemblies were applied to obtain three layers of gold on the surface of the MWCN $\mathrm{T}$. For this purpose, $20 \mathrm{mg}$ of MWCNT were mixed with $20 \mathrm{~mL}$ of $1 \%$ polydiallyldimethylammonium chloride solution and the mixture was taken to an ultrasonic bath for 10 min. Then, the solution with nanotubes was washed with ultrapure water and $20 \mathrm{~mL}$ of AuNPs solution were added to the flask; the mixture was taken to an ultrasonic bath and the non-assembled nanoparticles were removed by centrifugation; the volume extracted was replenished with a $\mathrm{NaOH}$ solution at $\mathrm{pH} 9.5$ for its last wash. The procedure was repeated 2 more times to obtain three layers of AuNPs anchored on MWCNT surface. The modified carbon nanotubes were dried in an oven at $80^{\circ} \mathrm{C}$ for $3 \mathrm{~h}$.

Subsequently, an ink was prepared with $2 \mathrm{mg}$ of MWCNT-AuNPs, $15 \mu \mathrm{L}$ of nafion and $500 \mu \mathrm{L}$ of distilled water. This mixture was agitated in an ultrasonic bath for $30 \mathrm{~min}$ to obtain a homogeneous dispersion. The procedure of ultrasonic bathing was repeated as often as necessary in order to maintain dispersion. Finally, the surface of a CF electrode of dimension $1 \times 4 \times 1 \mathrm{~cm}$ was impregnated with the ink through the drop casting technique and dried at $80^{\circ} \mathrm{C}$ for $30 \mathrm{~min}$.

\section{Characterization of MWCNT-AuNPs ink and MWCNT- AuNPs/CF}

A cell with three-electrode setup was used for the electrochemical characterization. A sample of MWCNT-AuNPs ink was placed on a glassy carbon (GC) disk electrode with $\mathrm{CF}$ of $1 \times 6 \times 1 \mathrm{~cm}$ used as counter electrode and $\mathrm{Ag} /$ $\mathrm{AgCl} / \mathrm{KCl}$ (sat) as reference electrode, and cyclic voltammetry $(\mathrm{CV})$ was performed in a solution of $0.5 \mathrm{M} \mathrm{H}_{2} \mathrm{SO}_{4}$. The measurements were made on an IviumStat potentiostat/galvanostat (Ivium Technologies. Eindhoven, Netherlands). Electrochemical characterization of the charge transfer capacitance of the CF modified with MWCNT-AuNPs was tested in an equimolar solution of $10 \mathrm{mM}$ of $\mathrm{Fe}(\mathrm{CN})_{6}{ }^{4-} / \mathrm{Fe}$ $(\mathrm{CN})_{6}{ }^{3-}$ that used $0.1 \mathrm{M} \mathrm{KCl}$ as supporting electrolyte at $10 \mathrm{mV} \mathrm{s}^{-1}$. CV was performed at scan rate of $1 \mathrm{mV} \mathrm{s}^{-1}$ and at potential range from -0.7 to $0.4 \mathrm{~V}$ (measured against an

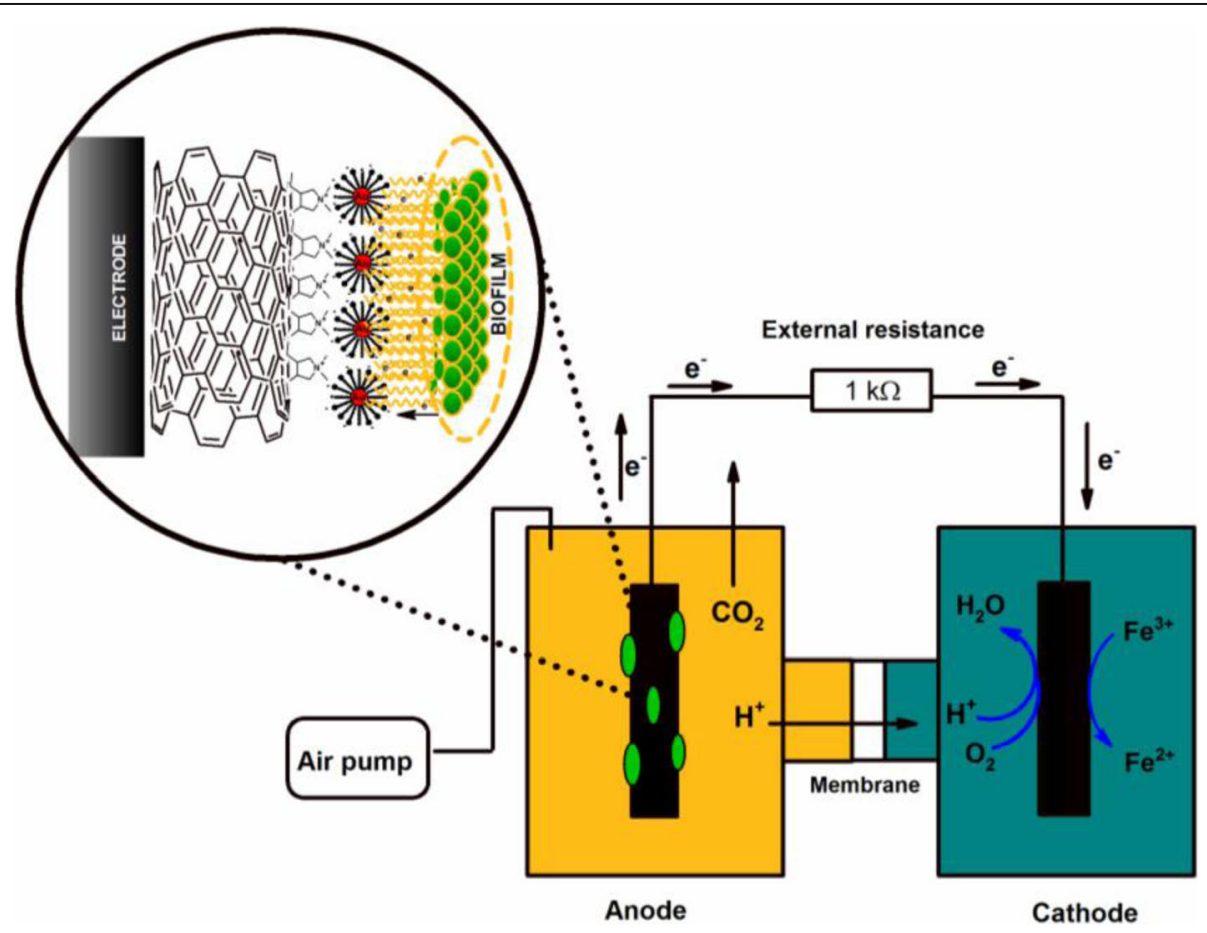

Fig. 1 MFC under aerobic conditions 
$\mathrm{Ag} / \mathrm{AgCl} / \mathrm{KCl}$ (sat) reference) in order to evaluate electrochemical activity of the used MFC.

\section{MFCs and electrical measurements}

MFCs had two polyhedral-shaped polyethylene containers $(11.5 \mathrm{~cm}$ length $\times 11.7 \mathrm{~cm}$ width $\times 7.5 \mathrm{~cm}$ height $)$. The total volume of each chamber was $900 \mathrm{~mL}$, but the volume used was $675 \mathrm{~mL}$. A proton exchange membrane (CMI7000) separated both chambers. The membrane thickness was $0.45 \pm 0.03 \mathrm{~mm}$ and the available surface area was $2.54 \mathrm{~cm}^{2}$. Before being used, the membrane was immersed in $5 \% \mathrm{NaCl}$ for $12 \mathrm{~h}$ in order to activate the membrane.

MWCNT-AuNPs/CF anode $(1 \times 4 \times 1 \mathrm{~cm})$ and $\mathrm{CF}$ without modified cathode $(4 \times 7 \times 1 \mathrm{~cm})$ were used. The anode/cathode area ratio of $1 / 7$ was established to avoid possible resistance interferences derived from the limit current density at the cathode. $\mathrm{Ag} / \mathrm{AgCl} / \mathrm{KCl}$ (sat.) reference electrode was placed in the anodic chamber. Both chambers were joined through an external resistor of $1000 \Omega$. Two cells were prepared with different culture media. On the one hand, synthetic wastewater (SWW) (4 g glucose, $310 \mathrm{mg} \quad \mathrm{NH}_{4} \mathrm{Cl}, 130 \mathrm{mg} \mathrm{KCl}, 4.97 \mathrm{~g}$ $\mathrm{NaH}_{2} \mathrm{PO}_{4}$ and $2.75 \mathrm{~g} \mathrm{Na}_{2} \mathrm{HPO}_{4} \cdot \mathrm{H}_{2} \mathrm{O}$ in $1 \mathrm{~L}, \mathrm{pH}$ 7.2) and LB (adjusted to $\mathrm{pH} 9$ with $\mathrm{NaOH}$ ) were used in anodic cell under aerobic conditions. On the other hand, in the cathodic chamber, a solution of $\mathrm{Fe}(\mathrm{CN})_{6}{ }^{3-}$ dissolved in $0.1 \mathrm{M} \mathrm{KCl}$ was used (Fig. 1). The electricity produced by electrical cells was controlled for $12 \mathrm{~d}$ while measuring voltage difference between the anode and the cathode through the external resistance, using a HANTEK ${ }^{\circ} 365 \mathrm{~A}$ data logger connected to a computer. The system was operated at room temperature.

\section{SEM of bioanode}

Scanning electron microscopy (SEM) was used for observing modified surface morphology of anodes. The

Table 1 Phenotypic characteristics of Shewanella spp. strain isolated compared to the reference strain ATCC 8071

\begin{tabular}{lll}
\hline Biochemical tests & S. putrefaciens ATCC 8071 & Shewanella spp. \\
\hline Mobility & + & + \\
Oxidase & + & + \\
Catalase & + & + \\
Indole production & - & - \\
$\mathrm{H}_{2}$ S production & + & + \\
Urea hydrolysis & - & - \\
Gelatin hydrolysis test & + & + \\
Nitrate test & + & + \\
Nitrite test & + & + \\
Hemolysis & - & - \\
Gram staining & - & - \\
\hline
\end{tabular}

+ Positive, - Negative electrodes were dried with hot air and stored in a desiccator. The images were obtained using a Philips 505 SEM at 10,000X magnification and applying an incident beam energy of $10 \mathrm{keV}$ with the working distance of 6.5 $\mathrm{mm}$. SEM characterization was repeated in order to observe biofilm formation on the carbon surface.

\section{MFC operating under anaerobic conditions}

After $12 \mathrm{~d}$ of biofilm growth in LB medium, the electrode was removed and stored for $15 \mathrm{~d}$ at $4{ }^{\circ} \mathrm{C}$. Subsequently, the electrode was installed in the MFC with fresh $0.1 \mathrm{M}$ acetate electrolyte under anaerobic conditions and the reactivation time was evaluated by the analysis of redox process versus immersion time.

\section{Results and discussion}

Isolation and identification of Shewanella spp.

After $24 \mathrm{~h}$, the marine samples deposited in the glass jars showed decomposition and at $48 \mathrm{~h}$ the process of putrefaction began. Shewanella spp. was isolated and biochemically identified from one of the marine samples. Table 1 shows the results of phenotypic and biochemical tests. After staining, bacteria appear as motile Gramnegative bacilli. The characteristics of the Shewanella strains on the SIM medium showed black, punctate colonies, $1-3 \mathrm{~mm}$ of diameter, giving off the smell of hydrogen sulfide. The colonies had mucous consistency. The published results of a $S$. putrefaciens strain ATCC 8071 were compared to the biochemical test results obtained from the isolated strains.

Phenotypic test results showed that Shewanella spp. was characterized by motile Gram-negative flagella with positive oxidase and catalase and $\mathrm{H}_{2} \mathrm{~S}$ production. These

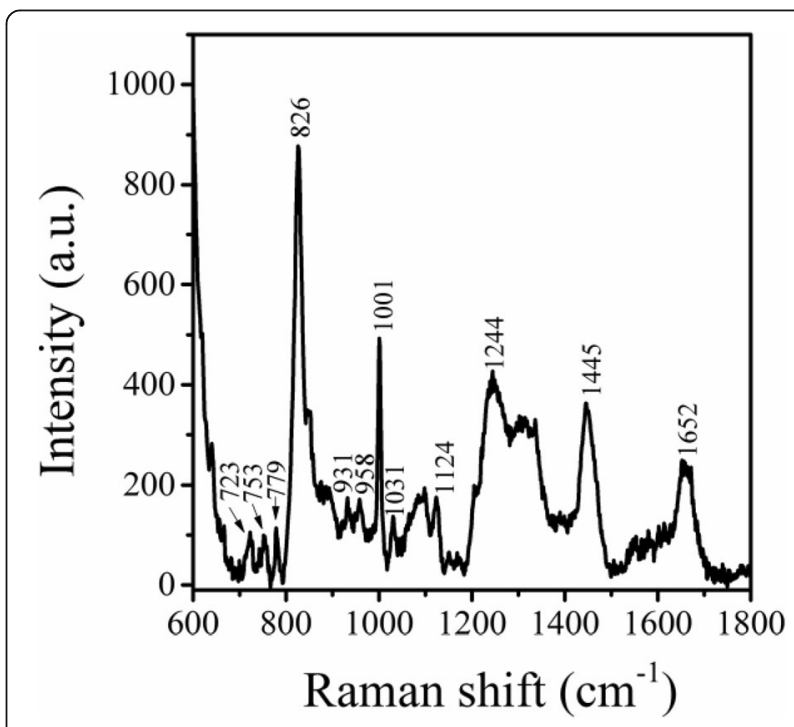

Fig. 2 Raman spectrum of Shewanella spp. on screen-printed gold electrodes collected by a diode laser $(638 \mathrm{~nm})$ 
Table 2 Structures of the main Raman bands $\left(\mathrm{cm}^{-1}\right)$ of Shewanella spp. isolated sample

\begin{tabular}{lll}
\hline Raman shift $\left(\mathbf{c m}^{-\mathbf{1}}\right)$ & Tentativa assignment of peaks & Refs. \\
\hline 723 & Adenine (glycosidic ring) & {$[29,30]$} \\
753 & $\begin{array}{l}\text { Tryptophan (symmetric stretch } \\
\text { of benzene) }\end{array}$ & {$[31]$} \\
779 & glycosidic ring & \\
826 & $\begin{array}{l}\text { Tyrosine protein (Fermi resonance } \\
\text { doublet) }\end{array}$ & {$[31]$} \\
931,958 & $\mathrm{C}-$ COO $^{-}$and C - C stretching & {$[30,31]$} \\
1001 & Tryptophan (symmetrical benzene & {$[30,31]$} \\
& and pyrrole ring stretch) & \\
1124 & NH $H_{3}^{+}$deformation & {$[30]$} \\
1244 & Amide III & {$[28,29]$} \\
1445 & $\mathrm{C}-\mathrm{H}_{2}$ deformation & {$[28,30]$} \\
1652 & Amide I & {$[30]$} \\
\hline
\end{tabular}

findings are consistent with those mentioned by Stenstrom and Molin [25] and Pekala et al. [26].

In addition, Shewanella spp. was analysed in the fingerprint region $\left(600-1800 \mathrm{~cm}^{-1}\right)$ of the spectra $[27,28]$. The spectra obtained for Shewanella spp. (Fig. 2) show peaks with values close to those reported by other investigations that used Shewanella species (Table 2) [28-31].

\section{Synthesis and characterization of CF electrode modified with MWCNT-AuNPs}

The synthesized AuNPs were characterized by UV-Vis absorption spectroscopy. AuNPs show the maximum absorption peak around $520 \mathrm{~nm}$ (Fig. 3a) [23]. In addition, dynamic light scattering analyzer (NanoBrook 90Plus, Brookhaven Instruments., New York, USA) was used to measure particle size (real refractive index $n_{s} 0.21$ and imaginary refractive index $k_{s} 3272$ ), obtaining an effective diameter of $30 \mathrm{~nm}$ (Fig. 3b).

The characterization of GC electrode modified with MWCNT-AuNPs was performed by using CV. Figure 3c shows the comparative voltammograms of MWCNT/GC and MWCNT-AuNPs/GC, observing the gold oxidation
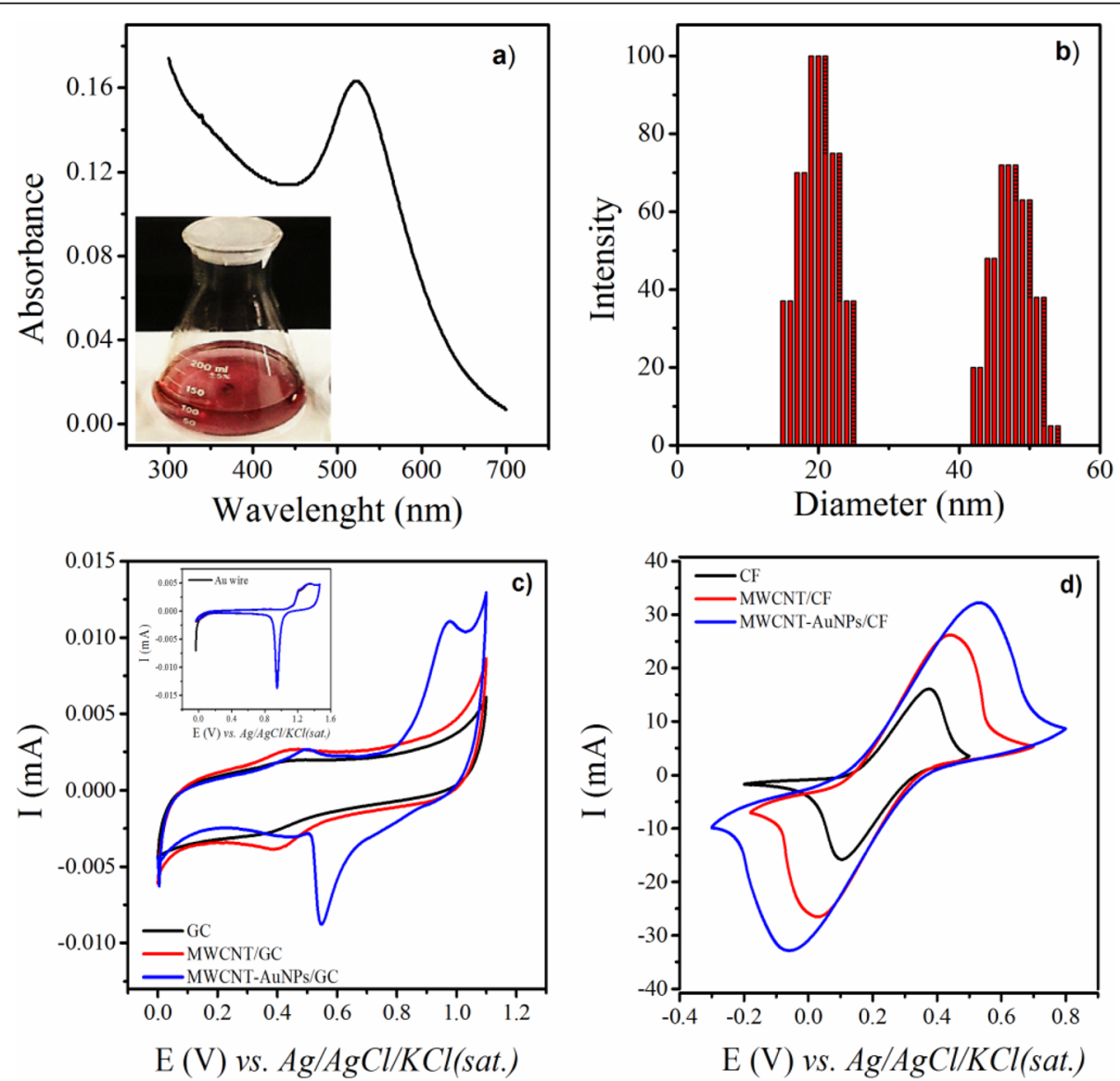

Fig. 3 a UV-Vis absorption spectrum of AuNPs. b Data obtained of AuNPs in the particle size analyzer. c CV in $0.5 \mathrm{M} \mathrm{H}_{2} \mathrm{SO}_{4}$ of GC, MWCNT/GC and MWCNT-AuNPs/GC, inset: gold wire. $\mathbf{d}$ in equimolar aqueous solution at $10 \mathrm{mM} \mathrm{Fe}(\mathrm{CN})_{6}{ }^{4-} / \mathrm{Fe}(\mathrm{CN})_{6}{ }^{3-}$ with $0.1 \mathrm{M} \mathrm{KCl}$ supporting electrolyte 

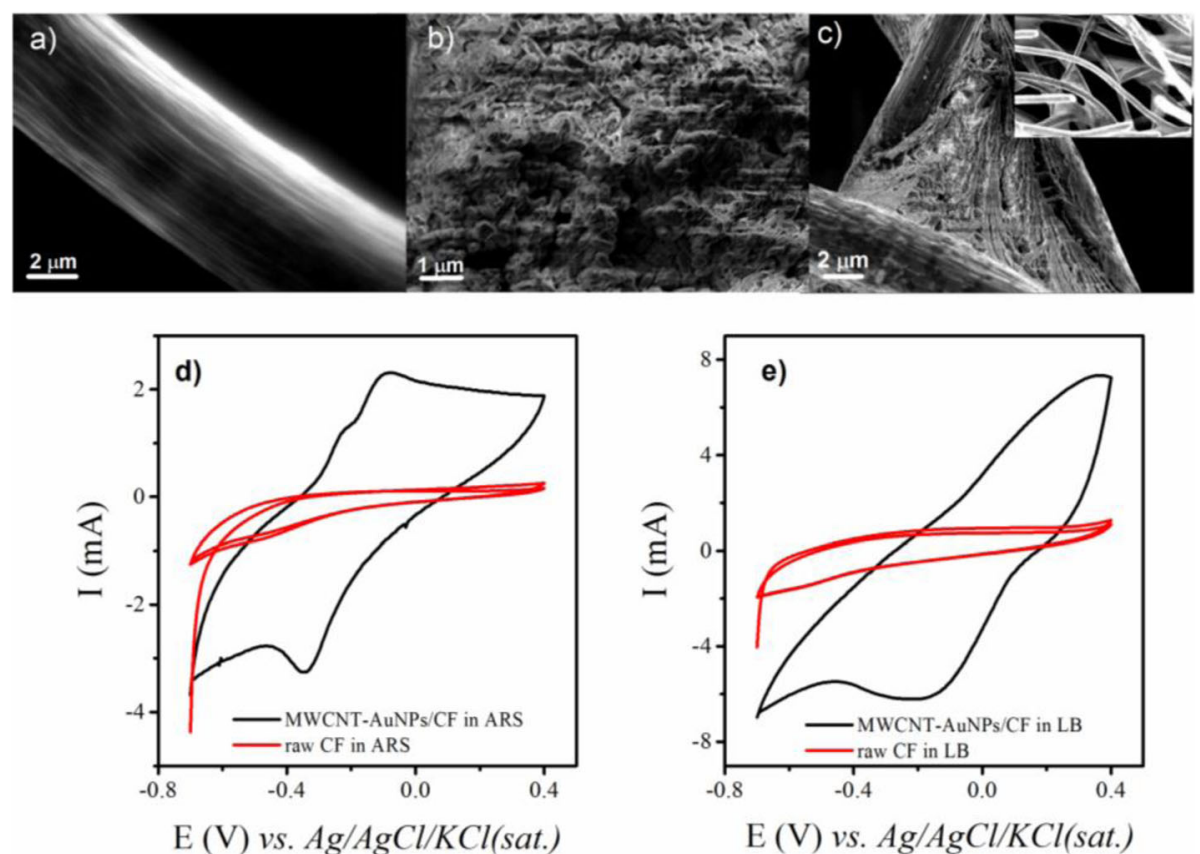

Fig. 4 a SEM images of CF. $\mathbf{b}$ biofilm on MWNCT-AuNPS/CF in SWW. $\mathbf{c}$ biofilm on MWNCT-AuNPs/CF in LB. $\mathbf{d}$ CVs in SWW of CF and MWNCTAuNPs/CF with biofilm. e with LB

and reduction peaks at 0.95 and $0.55 \mathrm{~V}$ vs. $\mathrm{Ag} / \mathrm{AgCl} /$ $\mathrm{KCl}$ (sat.), respectively, coinciding with the redox potentials obtained from a gold electrode used as reference (see inset Fig. 3c). Moreover, the running CVs of the CF electrodes modified with MWCNT and MWCNTAuNPs in $\left[\mathrm{Fe}(\mathrm{CN})_{6}\right]^{4-} /\left[\mathrm{Fe}(\mathrm{CN})_{6}\right]^{3-} / \mathrm{KCl}$ solution show a significant increase in peak current with respect to the unmodified electrode, from 15.4 to 27.7 and $31.5 \mathrm{~mA}$ (Fig. 3d). This increase in current may be related to the increase in the electroactive area and the conductivity generated by MWCNT and AuNPs in MWCNT-AuNPs $\left(0.012 \mathrm{mg} \mathrm{m}^{-2}\right.$ of $\left.\mathrm{Au}\right)$. However, the displacement of the potential is an indicator of a greater difficulty of the electrolyte diffusion in nanotubes. Assuming a proportional relationship between the heights of anodic current and the area (Butler-Volmer equation), it was obtained an initial electroactive area of $0.12 \mathrm{~m}^{2}$ for unmodified CF and $0.43 \mathrm{~m}^{2}$ for MWCNT-AuNPs/CF.

The SEM micrograph analysis shows the fibers of the unmodified CF (Fig. 4a). Figure 4b shows the fibers completely covered with the biofilm formed after $5 \mathrm{~d}$ of culture in SWW medium. Likewise, it was noted the formation of a biofilm that extends over the fibers in the felt immersed in LB (Fig. 4c). This characteristic should be considered in the evaluation of the electrode efficiency. Therefore, these results show the biocompatibility of the materials used and the morphological modification, which occurs during the biofilm formation and growth on the surfaces of CF modified with MWNCT-AuNPs.
In addition, the voltammograms of Fig. $4 \mathrm{~d}$ and e, corresponding to the CF electrode immersed in SWW and LB media, respectively, show two wide oxidation peaks around -0.2 and $-0.1 \mathrm{~V}$ and a reduction band around $-0.3 \mathrm{~V}$ vs. $\mathrm{Ag} / \mathrm{AgCl} / \mathrm{KCl}$ (sat). Redox process shows the facultative nature of the Shewanella spp. bacteria, due to their electrochemical activity under aerobic conditions. The potentials obtained in the voltammograms are close to the potentials reported in other investigations that used Shewanella under anaerobic conditions [3, 5, 32]. Thus, the results would reveal that electrochemical activity also occurs in aerobically growing bacteria and this activity probably depends on the type of substrate since the results show a better visualization of the redox reaction in SWW (Fig. 4d).

\section{Evaluation of bioelectrochemical energy production in SWW and LB}

The difference of potential versus the time was recorded during 12 days of biofilm growth over the anode of MWNCT-AuNPs/CF (Fig. 5a and b). Potential of an unmodified CF was measured simultaneously in another microbial cell. It was noted a potential increased with the passing of the hours and in the power production profile the power density generation changes with the type of substrate. The MFC was evaluated during the first $12 \mathrm{~d}$, and a stabilized power density value 71 and $281 \mathrm{~mW} \mathrm{~m}^{-2}$ were obtained in the SWW and the LB 

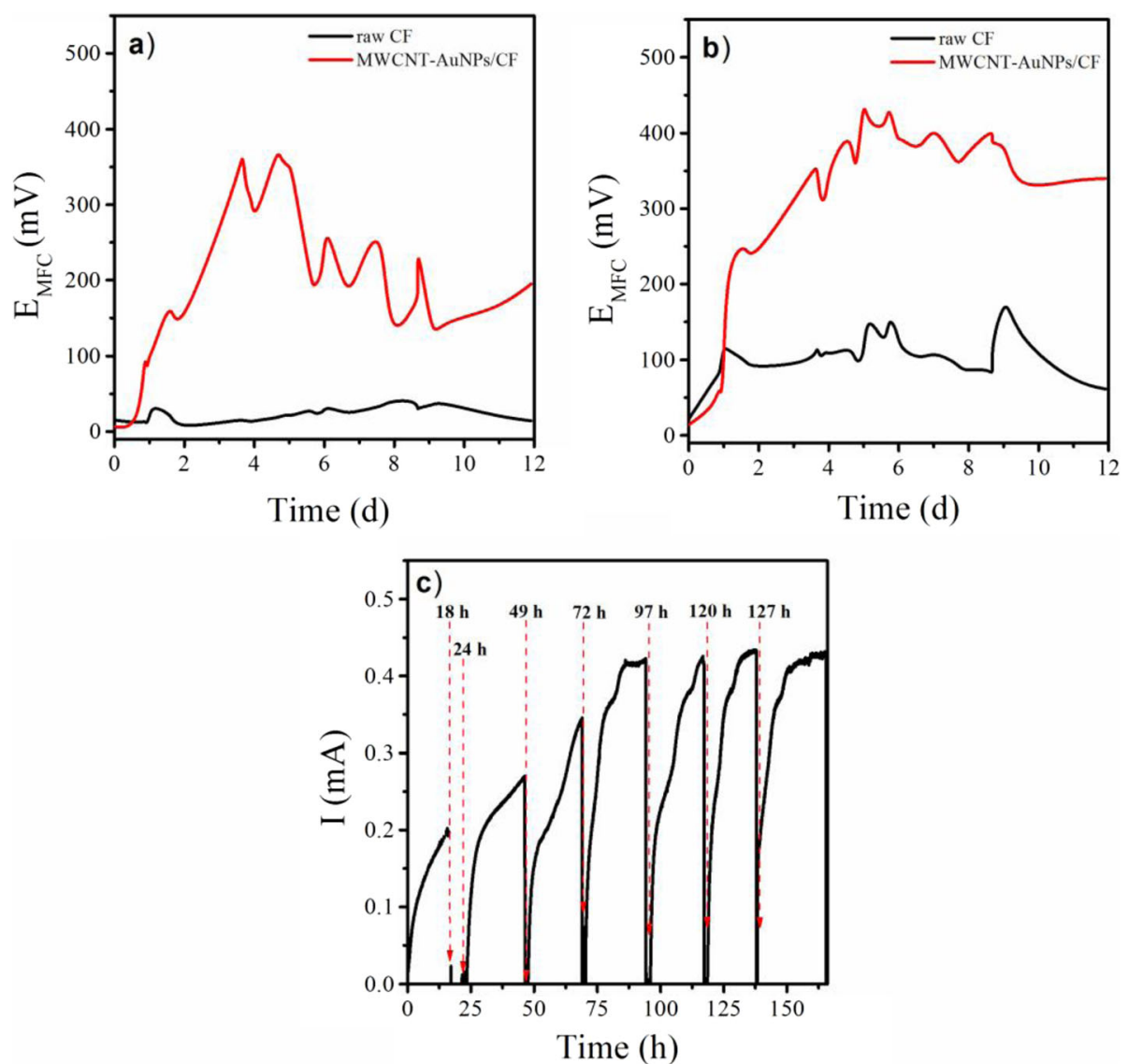

Fig. 5 a Cell performance over time in aerobic conditions of CF and MWCNT-AuNPS/CF in SWW. $\mathbf{b}$ in LB. c Chronoamperometry of biofilm on MWCNT-AuNPs/CF, applied potential at $0.2 \mathrm{~V}$ vs. Ag/AgCl/KCl(sat.) in anaerobic conditions. The arrows indicate the addition of $0.1 \mathrm{M}$ acetate

substrates, respectively. These values were determined using the following equation (Eq. (1)) [33]:

$$
P=\frac{E_{M F C}^{2}}{A_{A n} R_{e x t}}
$$

where, $\mathrm{P}$ is the stabilized power density, $\mathrm{E}_{\mathrm{MFC}}$ is the MFC stabilized potential, $A_{a n}$ is the anodic area and $R_{\text {ext }}=1 \mathrm{k} \Omega$ is the external resistance employed.

Moreover, the power generated in the LB medium is almost twice that obtained in the SWW medium. The results may be related to the components of culture media, since a percentage of glucose (the main component of the SWW) carries out a parallel reaction that generates fermentation products according to the following (Eqs. 2 and 3) [34, 35]:

$$
\begin{aligned}
& \mathrm{C}_{6} \mathrm{H}_{12} \mathrm{O}_{6}+2 \mathrm{H}_{2} \mathrm{O} \rightarrow 4 \mathrm{H}_{2}+2 \mathrm{CO}_{2}+2 \mathrm{C}_{2} \mathrm{H}_{4} \mathrm{O}_{2} \\
& \mathrm{C}_{6} \mathrm{H}_{12} \mathrm{O}_{6} \rightarrow 2 \mathrm{H}_{2}+2 \mathrm{CO}_{2}+\mathrm{C}_{4} \mathrm{H}_{8} \mathrm{O}_{2}
\end{aligned}
$$

While in the LB medium, due to its main content of tryptone (enzymatic digest of casein), microorganisms use the available nitrogen source, avoiding fermentation.
Therefore, the LB medium turned out to be favourable for the generation of electrical energy.

Figure $5 \mathrm{c}$ shows the current produced in the anode. Each dotted line represents the time when the substrate in the MFC was replaced with fresh acetate substrate. Initially, no current was recorded, but with time, there is a progressive increase in current at an approximate rate of $0.023 \mathrm{~mA} \mathrm{~m}^{-2} \mathrm{~h}^{-1}$ reaching a maximum current density in the steady state of $0.11 \mathrm{~mA} \mathrm{~cm}^{-2}$ after $72 \mathrm{~h}$. The coulombic efficiency was determined by chronoamperometry. In this case, a $700 \mathrm{~mL}$ cell was used to which $0.8 \mathrm{~g}$ of acetate was added along with recording time and current data produced by the MFC during a cycle of $16.4 \mathrm{~h}$. Integration of these data from the equation, $\mathrm{Q}=\mathrm{I} \mathrm{t}$, resulting in $\mathrm{Qa}=$ 1193 C. In the meantime, the chemical oxygen demand (COD) was analyzed at the beginning and end of the experiment. The coulombic efficiency is determined from the comparison of the measured charge against the charge produced by the combustion of the consumed acetate during the time of the experiment.

The COD values analyzed were: COD at $0 \mathrm{~h}=1076$ $\mathrm{mg} \mathrm{L}^{-1}$; COD at $16.4 \mathrm{~h}=646 \mathrm{mg} \mathrm{L}^{-1}$. Thus, the total charge obtained from the combustion of the acetate was, 
Qc $=1841$ C. Coulombic efficiency is thus calculated as Qa/Qc or $1193 / 1841=65 \%$.

Furthermore, the evaluation by $\mathrm{CV}$ of the electrodes immersed in the new substrate allowed to observe the redox process after $18 \mathrm{~h}$ of measurement (Fig. 6a and b). The potentials recorded at 0.08 and $-0.28 \mathrm{~V}$ represent the redox process that occurs in microbial reaction. Redox potentials were not observed during the first hours due to the new substrate that inhibited bacterial activity. Figure 6c shows peak current variations during the bacteria adaptation. The increase in the peak current is related to the growth in the number of redox species in the electrodes that represent an increment in the electrochemical activity of bacteria. This result favors production of electric current.

According to the results, it is conclusive that the incorporation of MWCNT and AuNPs contributes significantly to the increase in energy of the MFC, it is possible to associate this increase with several factors, among them, the increase in energy density, as well as the decrease of ohmic resistance favoring its high electrical conductivity. The presence of AuNPs can improve the biocompatibility of exoelectrogenic bacteria to form a stable biofilm on the electrode surface, increasing its coulombic efficiency. Table 3 shows the comparative results with those obtained in the present work.

The metabolic process of bacteria, which produces energy and gases along with growth of biofilm of uncontrolled thickness, codeposition of particles from salts and other interferers can affect the stability of the electrode, so future studies aimed at evaluating the effects mentioned in the cell lifetime are necessary.

\section{Conclusions}

It is possible to design a double-compartment MFC, separated with a cationic membrane, using Shewanella strains isolated from $O$. regia regia as inocula. The surface modification of CF electrodes with AuNPs and
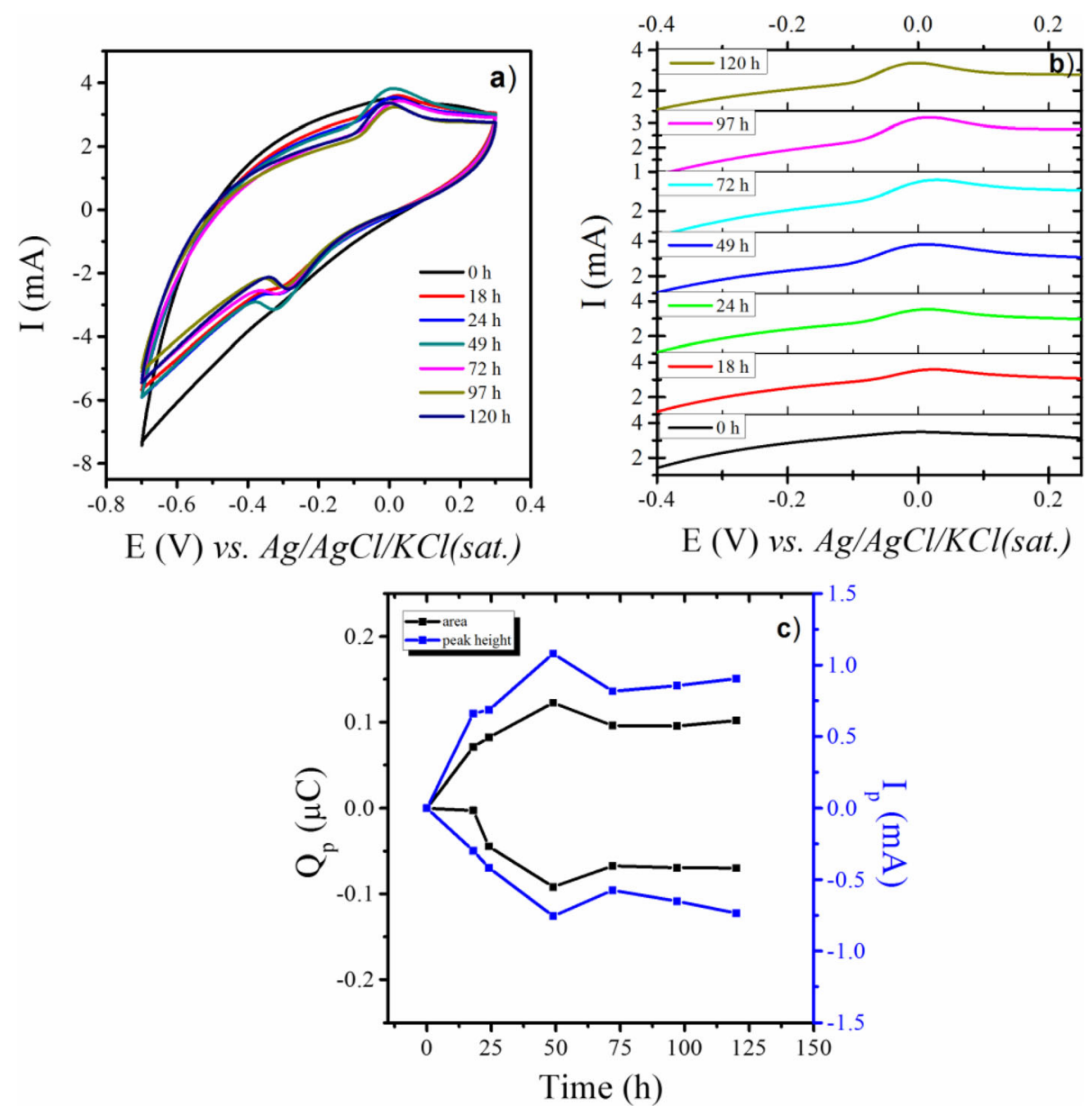

Fig. 6 a CV of CF with microbial biofilm immersed in a electrochemical cell containing industrial wastewater, at scan rate of $1 \mathrm{mV} \mathrm{s} \mathrm{s}^{-1} \mathrm{vs}$. Ag/ $\mathrm{AgCl} / \mathrm{KCl}$ (sat.). $\mathbf{b}$ Amplification of the anode peak of the modified CF with biofilm augmentation over time. $\mathbf{c}$ Height $\left(\mathrm{I}_{\mathrm{p}}\right)$ and area $\left(\mathrm{Q}_{\mathrm{p}}\right)$ for the oxidation and reduction peaks of redox system, depending on their potential measured at $1 \mathrm{mV} \mathrm{s}^{-1} \mathrm{vs}$. Ag/ $\mathrm{AgCl} / \mathrm{KCl}($ (sat.). For visualization purposes, reduction peaks were considered as negative values 
Table 3 Comparative values of energy density obtained in studies of MFCs

\begin{tabular}{llll}
\hline Anode & Inoculum/substrate & Power density $\left.\mathbf{~ ( m W ~} \mathbf{~}^{\mathbf{- 2}}\right)$ & Refs. \\
\hline CF modified with PANI & Mixed culture/acetate & 216 & {$[36]$} \\
CF modified with graphene oxide (GO) & S. putrefaciens/LB + Lactate & 240 & {$[37]$} \\
CF modified with GO-zeolite & Sludge/acetate & 281 & {$[38]$} \\
Iron-plated CF & S. oneidensis MR-1/LB + lactic acid & 113 & {$[39]$} \\
CF modified with MWCNT-AuNPs & Shewanella spp./LB & 281 & This study \\
CF modified with & Shewanella spp./SWW & 135 & This study \\
MWCNT-AuNPs & & & \\
\hline
\end{tabular}

MWCNT proved to be useful for increasing electrical conductivity and electrode biocompatibility.

Additionally, studies by CV allowed the observation of electrochemical activity of Shewanella spp. biofilm formation under aerobic and anaerobic conditions. The placement of the electrode with biofilm grown in a new system with real wastewater presented the same electricity generation capacity. This finding opens the possibilities of the use of electrodes with stable biofilms in substrates with oxygen content. Besides, these results extend the possibilities of research on applications for other optional type of bacteria in MFC.

\section{Acknowledgements}

The authors gratefully acknowledge the financial support given by InnóvatePerú-FINCYT (Contract 367-PNICP-PIAP-2014) and the institutional support and intellectual stimulation received from the Research Institute of the Faculty of Sciences, National University of Engineering. The authors thank the support of Dr. German Buitrón Méndez from the Instituto de Ingeniería, Universidad Nacional Autónoma de México, for his support in the Laboratorio de Juriquilla, and Dr. Gabriel Planes from Universidad Nacional de Río Cuarto for helping with SEM analysis.

\begin{abstract}
Authors' contributions
Sandy Luz Calderon performed the experimental work in the laboratory, obtained data, and produced the report. Pilar García, isolated, cultivated and characterized the strains of bacteria, doping for use in microbial fuel cells. Angelica Baena Moncada, contributed with the knowledge of supported nanoparticles on carbon materials and its adaptation on MFC, and the revision of the manuscript. Ana Lucía Paredes, participated in the discussion of results and wrote the manuscript. Adolfo La Rosa Toro Gómez, coordinated the work team, contributed with experience and knowledge on microbiological fuel cells and contributed to the discussion of results. All authors read and approved the final manuscript.
\end{abstract}

\section{Funding}

This work was supported by Innóvate-Perú-FINCYT (Contract 367-PNICP-PIAP2014) and the Research Institute of the Faculty of Sciences, National University of Engineering.

\section{Availability of data and materials}

All data generated or analysed during this study are included in this published article and its supplementary information files.

\section{Competing interests}

The authors declare that they have no competing interests" in this section.
Received: 26 April 2020 Accepted: 11 November 2020

Published online: 25 November 2020

\section{References}

1. Scott K, Yu EH, Ghangrekar MM, Erable B, Duteanu NM. Biological and microbial fuel cells. In: Sayigh A, editor. Comprehensive renewable energy. Amsterdam: Elsevier; 2012. p. 277-300.

2. Santoro C, Arbizzani C, Erable B, leropoulos I. Microbial fuel cells: from fundamentals to applications. A review. J Power Sources. 2017:356:225-44.

3. Virdis B, Millo D, Donose BC, Batstone DJ. Real-time measurements of the redox states of c-type cytochromes in electroactive biofilms: a confocal resonance Raman microscopy study. PloS One. 2014;9:e89918.

4. Rabaey K, Boon N, Siciliano SD, Verhaege M, Verstraete W. Biofuel cells select for microbial consortia that self-mediate electron transfer. Appl Environ Microb. 2004;70:5373-82.

5. Carmona-Martinez AA, Harnisch F, Kuhlicke U, Neu TR, Schroder U. Electron transfer and biofilm formation of Shewanella putrefaciens as function of anode potential. Bioelectrochemistry. 2013;93:23-9.

6. Pandit S, Khilari S, Roy S, Pradhan D, Das D. Improvement of power generation using Shewanella putrefaciens mediated bioanode in a single chambered microbial fuel cell: effect of different anodic operating conditions. Bioresour Technol. 2014;166:451-7.

7. Derby HA, Hammer BW. Bacteriology of butter IV. Bacteriological studies on surface taint butter. lowa AHEES Res Bull. 1931;11:1.

8. Shewan JM. The microbiology of fish and fishery products-a progress report. J Appl Bacteriol. 1971;34:299-315.

9. Bagge D, Hjelm M, Johansen C, Huber I, Grami L. Shewanella putrefaciens adhesion and biofilm formation on food processing surfaces. Appl Environ Microb. 2001:67:2319-25.

10. Ge BC, Li KX, Fu Z, Pu LT, Zhang X, Liu ZQ, et al. The performance of nano urchin-like $\mathrm{NiCO}_{2} \mathrm{O}_{4}$ modified activated carbon as air cathode for microbial fuel cell. J Power Sources. 2016;303:325-32.

11. Xu HD, Quan XC, Xiao ZT, Chen L. Effect of anodes decoration with metal and metal oxides nanoparticles on pharmaceutically active compounds removal and power generation in microbial fuel cells. Chem Eng J. 2018;335:539-47.

12. Nguyen MT, Mecheri B, Iannaci A, D'Epifanio A, Licoccia S. Iron/polyindolebased electrocatalysts to enhance oxygen reduction in microbial fuel cells. Electrochim Acta. 2016:190:388-95.

13. Asensio Y, Montes IB, Fernandez-Marchante CM, Lobato J, Canizares P, Rodrigo MA. Selection of cheap electrodes for two-compartment microbial fuel cells. J Electroanal Chem. 2017;785:235-40.

14. Wu SJ, He WH, Yang WL, Ye YL, Huang X, Logan BE. Combined carbon mesh and small graphite fiber brush anodes to enhance and stabilize power generation in microbial fuel cells treating domestic wastewater. J Power Sources. 2017:356:348-55.

15. Hidalgo D, Tommasi T, Bocchini S, Chiolerio A, Chiodoni A, Mazzarino I, et al. Surface modification of commercial carbon felt used as anode for microbial fuel cells. Energy. 2016;99:193-201.

16. Chen M, Zhou XF, Liu X, Zeng RJ, Zhang F, Ye J, et al. Facilitated extracellular electron transfer of Geobacter sulfurreducens biofilm with in situ formed gold nanoparticles. Biosens Bioelectron. 2018;108:20-6.

17. Stoner BR, Brown B, Glass JT. Selected topics on the synthesis, properties and applications of multiwalled carbon nanotubes. Diam Relat Mater. 2014:42:49-57.

18. Cai T, Huang YX, Huang MH, Xi Y, Pang DY, Zhang W. Enhancing oxygen reduction reaction of supercapacitor microbial fuel cells with electrospun carbon nanofibers composite cathode. Chem Eng J. 2019;371:544-53. 
19. Cai T, Huang MH, Huang YX, Zheng W. Enhanced performance of microbial fuel cells by electrospinning carbon nanofibers hybrid carbon nanotubes composite anode. Int J Hydrogen Energ. 2019;44:3088-98.

20. Peng L, You SJ, Wang JY. Carbon nanotubes as electrode modifier promoting direct electron transfer from Shewanella oneidensis. Biosens Bioelectron. 2010;25:1248-51.

21. Austin B. Taxonomy of bacterial fish pathogens. Vet Res. 2011;42:20.

22. Holt HM, Gahrn-Hansen B, Bruun B. Shewanella algae and Shewanella putrefaciens: clinical and microbiological characteristics. Clin Microbiol Infec. 2005;11:347-52.

23. Selvakannan PR, Swami A, Srisathiyanarayanan D, Shirude PS, Pasricha R, Mandale AB, et al. Synthesis of aqueous Au core-Ag shell nanoparticles using tyrosine as a pH-dependent reducing agent and assembling phase-transferred silver nanoparticles at the air-water interface. Langmuir. 2004;20:7825-36.

24. Decher G, Eckle M, Schmitt J, Struth B. Layer-by-layer assembled multicomposite films. Curr Opin Colloid Int. 1998;3:32-9.

25. Stenstrom IM, Molin G. Classification of the spoilage flora of fish, with special reference to Shewanella putrefaciens. J Appl Bacteriol. 1990;68:601-18.

26. Pekala A, Kozinska A, Pazdzior E, Glowacka H. Phenotypical and genotypical characterization of Shewanella putrefaciens strains isolated from diseased freshwater fish. J Fish Dis. 2015;38:283-93.

27. Huang WE, Griffiths RI, Thompson IP, Bailey MJ, Whiteley AS. Raman microscopic analysis of single microbial cells. Anal Chem. 2004;76:4452-8.

28. Chao YQ, Zhang T. Surface-enhanced Raman scattering (SERS) revealing chemical variation during biofilm formation: from initial attachment to mature biofilm. Anal Bioanal Chem. 2012:404:1465-75.

29. Ivleva NP, Wagner M, Horn H, Niessner R, Haisch C. In situ surface-enhanced Raman scattering analysis of biofilm. Anal Chem. 2008;80:8538-44.

30. Yang X, Gu C, Qian F, Li Y, Zhang JZ. Highly sensitive detection of proteins and bacteria in aqueous solution using surface-enhanced Raman scattering and optical fibers. Anal Chem 2011;83:5888-94.

31. Storrie-Lombardi MC, Hug WF, McDonald GD, Tsapin Al, Nealson KH. Hollow cathode ion lasers for deep ultraviolet Raman spectroscopy and fluorescence imaging. Rev Sci Instrum. 2001;72:4452-9.

32. Kim HJ, Park HS, Hyun MS, Chang IS, Kim M, Kim BH. A mediator-less microbial fuel cell using a metal reducing bacterium, Shewanella putrefaciens. Enzyme Microb Tech. 2002:30:145-52.

33. Logan BE, Hamelers B, Rozendal R, Schroder U, Keller J, Freguia S, et al. Microbial fuel cells: methodology and technology. Environ Sci Technol. 2006; 40:5181-92.

34. Rabaey K, Verstraete W. Microbial fuel cells: novel biotechnology for energy generation. Trends Biotechnol. 2005;23:291-8.

35. Chae KJ, Choi MJ, Lee JW, Kim KY, Kim IS. Effect of different substrates on the performance, bacterial diversity, and bacterial viability in microbial fuel cells. Bioresour Technol. 2009;100:3518-25.

36. Rajesh PP, Noori MT, Ghangrekar MM. Improving performance of microbial fuel cell by using polyaniline-coated carbon-felt anode. J Hazard Toxic Radioact Waste. 2020;24:04020024.

37. Zhu WH, Yao M, Gao HX, Wen H, Zhao XL, Zhang JF, et al. Enhanced extracellular electron transfer between Shewanella putrefaciens and carbon felt electrode modified by bio-reduced graphene oxide. Sci Total Environ. 2019;691:1089-97.

38. Paul D, Noori MT, Rajesh PP, Ghangrekar MM, Mitra A. Modification of carbon felt anode with graphene oxide-zeolite composite for enhancing the performance of microbial fuel cell. Sustain Energy Techn. 2018;26:77-82.

39. Phansroy N, Khawdas W, Watanabe K, Aso Y, Ohara H. Microbial fuel cells equipped with an iron-plated carbon-felt anode and Shewanella oneidensis MR-1 with corn steep liquor as a fuel. J Biosci Bioeng. 2018;126:514-21.

\section{Publisher's Note}

Springer Nature remains neutral with regard to jurisdictional claims in published maps and institutional affiliations.

Ready to submit your research? Choose BMC and benefit from:

- fast, convenient online submission

- thorough peer review by experienced researchers in your field

- rapid publication on acceptance

- support for research data, including large and complex data types

- gold Open Access which fosters wider collaboration and increased citations

- maximum visibility for your research: over $100 \mathrm{M}$ website views per year

At $\mathrm{BMC}$, research is always in progress.

Learn more biomedcentral.com/submissions 